\title{
Krzysztof Kaszewski
}

ORCID: 0000-0002-8789-2405

Uniwersytet Warszawski

https://doi.org/10.19195/1642-5782.19(29).3

\section{Argument a przykład w rozprawce}

W obecnie obowiązującej podstawie programowej ${ }^{1}$ sporo uwagi poświęca się wypowiedziom argumentacyjnym, a jednym z zagadnień szczegółowych z tym związanych jest odróżnianie argumentu od przykładu. Obecność tego zapisu to, z jednej strony, reakcja na rzeczywistość szkolną (uczniowskie skłonności widoczne w pracach pisemnych), z drugiej — nowość skłaniająca do refleksji metodycznej. W artykule omawiam oczekiwania dotyczące argumentacji w pracach uczniów sformułowane w podstawie programowej i wymaganiach egzaminacyjnych (zwłaszcza na egzaminie maturalnym od 2023 roku), wskazuję potencjalne korzyści i wady proponowanego rozwiązania oraz przedstawiam propozycje działań dydaktycznych mających pomóc uczniom budować rzeteln(iejsz)ą argumentację w swoich wypowiedziach ${ }^{2}$.

\section{Argument a przykład w uczniowskiej rozprawce - oczekiwania}

Według słowników języka polskiego argument to „fakt, który przytaczamy, aby uzasadnić lub obalić jakąś tezę, albo środek, którego używamy w dyskusji lub

${ }^{1}$ Rozporządzenie Ministra Edukacji Narodowej z dnia 14 lutego 2017 roku w sprawie podstawy programowej wychowania przedszkolnego oraz podstawy programowej kształcenia ogólnego dla szkoły podstawowej, w tym dla uczniów z niepełnosprawnością intelektualną w stopniu umiarkowanym lub znacznym, kształcenia ogólnego dla branżowej szkoły I stopnia, kształcenia ogólnego dla szkoły specjalnej przysposabiającej do pracy oraz kształcenia ogólnego dla szkoły policealnej, Dz.U. z 2017 r. poz. 356, http://isap.sejm.gov.pl/isap.nsf/DocDetails.xsp?id=WDU20170000356 (dostęp: 11.06.2021).

${ }^{2}$ Tezy niniejszego artykułu były przedmiotem dyskusji w czasie seminarium naukowego „Argument a przykład w szkolnej rozprawce", zorganizowanego przez Pracownię Badań Edukacji Polonistycznej i Medialnej na Wydziale Polonistyki UW (Warszawa, 20 maja 2021 roku). Wszystkim uczestniczkom i uczestnikom tego spotkania serdeczne dziękuję za podpowiedzi, polemiki i inspiracje. 
sporze, aby przekonać lub nakłonić kogoś do czegoś”3 bądź „fakt lub przekonanie służące do uzasadnienia jakichś racji lub decyzji” ${ }^{4}$. Z kolei przykład to „rzecz, osoba, sytuacja itp., którą przytaczamy, aby zilustrować jakąś myśl lub uzasadnić jakieś stwierdzenie" bądź ,akt mogący służyć za ilustrację, dowód, poparcie czegoś, jakiegoś twierdzenia"'

Powyższe rozróżnienie zostało uwypuklone w obowiązującej obecnie podstawie programowej nauczania języka polskiego: w części Tworzenie wypowiedzi dla klas 7-8 szkoły podstawowej znalazł się zapis: „,[Uczeń] odróżnia przykład od argumentu". Oczekuje się więc, że w uczniowskiej rozprawce argumentem będzie ogólne stwierdzenie uzasadniające lub obalające tezę lub przyjęte stanowisko, zrozumiałe i sensowne uniwersalnie, czyli (jeszcze) bez odniesienia do konkretnych osób, postaci, sytuacji itp., przykład zaś będzie taki argument ilustrować, ukonkretniać, wzbogacać, rozwijać, uzupełniać, doprecyzowywać. Mogą nim być różnego rodzaju konkretne dane, na przykład treść dzieła kultury, elementy wiedzy o świecie, doświadczenia życiowe. Jego rolą jest ukazać, że to, co stwierdza ogólnie argument, przekłada się na fakty lub zdarzenia fikcyjne (przedstawione w dziełach kultury).

Projektowaną w podstawie programowej relację między argumentem a przykładem w rozprawce ukazują przypadki ${ }^{7} 1$ i 2.

\section{Przypadek 1}

Temat: Rozum czy uczucia - czym bardziej powinniśmy kierować się w życiu?

Teza: Uczucia

Argument: Uczucia pozwalają stworzyć więź z drugim człowiekiem

Przykład: Odwołanie się do dzieła ukazującego miłość czy przyjaźń, na przykład Małego Księcia

\section{Przypadek 2}

Temat: Czy cierpienie ma sens?

Teza: Prawda

Argument: Cierpienie może zbliżyć człowieka do Boga

Przykład: Zwięzłe przedstawienie treści dzieła pokazującego, jak ktoś cierpiący się nawrócił — na przykład dzieje św. Aleksego

W przypadkach 1 i 2 najpierw pojawia się argument, czyli ogólne stwierdzenie popierające postawioną wcześniej tezę. Do tak sformułowanej generalizacji, spójnej z tematem i tezą, autonomicznej (choć jednocześnie ogólnikowej), dokła-

\footnotetext{
${ }^{3}$ Inny słownik języka polskiego, t. 1, red. M. Bańko, Warszawa 2001-2002, s. 41.

${ }^{4}$ Uniwersalny stownik języka polskiego, red. S. Dubisz, Warszawa 2004.

${ }^{5}$ Inny stownik..., t. 2, s. 366.

${ }^{6}$ Uniwersalny stownik...

${ }^{7}$ Przywoływane tematy rozprawkowe nazywam przypadkami, a nie przykładami, by uniknąć zamieszania (wieloznaczność) i monotonii.
} 
da się wybrane ukonkretnienie - przykłady odwołujące się do treści poszczególnych dzieł kultury. Co bardzo ważne, nic nie stoi na przeszkodzie, by jeden argument został zilustrowany za pomocą dwóch czy trzech przykładów.

$\mathrm{Na}$ odróżnianie argumentu od przykładu zwraca się też uwagę w kryteriach oceniania na egzaminie maturalnym. Czytamy między innymi, że bogata lub zadowalająca argumentacja poparta jest przykładami ${ }^{8}$ oraz że ,utwór literacki nie jest wykorzystany funkcjonalnie, jeżeli zdający wyłącznie streszcza ten utwór lub wybrane jego wątki, ale nie wyciąga żadnego wniosku, nie formułuje żadnej refleksji związanej ze streszczonym utworem" ". Wspomniane tu wniosek oraz refleksja to stwierdzenia w rodzaju argumentu, zaś streszczenie jest bliskie przykładowi.

\section{Odróżnianie argumentu od przykładu - co zyskujemy?}

Zwrócenie uwagi na odróżnianie argumentu i przykładu może przynieść korzyści dwojakiego rodzaju. Z jednej strony, pomaga (wy)eliminować typowe błędy w pracach uczniowskich, z drugiej — pozwala ćwiczyć kilka ważnych umiejętności przydatnych nie tylko podczas pisania wypowiedzi argumentacyjnej.

Jednym z podstawowych błędów w uczniowskich rozprawkach jest sprowadzanie argumentacji do opisu treści przywołanych dzieł, czasami z elementami interpretacji, ale bez jasno sformułowanej myśli ogólnej potwierdzającej tezę postawioną na wstępie rozważań. Ilustrują to poniższe przypadki 3 i 4.

\section{Przypadek 3}

Temat: Czy cierpienie ma sens?

Teza: Prawda

Wybrany akapit argumentacyjny: Moim pierwszym argumentem jest film Trzy metry na ziemia [...] Film opowiada o tym, że pewien chłopak poznaje dziewczynę, na początku ich związku wszystko się układa, obydwoje są szczęśliwi i się kochają, lecz pod koniec ich relacja zaczyna sie rozwalać i się rozstają i obydwoje cierpią. W kolejnej części chłopak poznaje nową dziewczynę, a dzięki temu cierpieniu, które odczuwał, jego związek z nową dziewczyną się udał, bo chłopak wiedział, czego nie robić w związku.

\section{Przypadek 4}

Temat: Rozum czy uczucia — czym bardziej powinniśmy kierować się w życiu?

Teza: Uczucia

${ }^{8}$ INFORMATOR o egzaminie maturalnym z języka polskiego jako przedmiotu obowiazkowego (część ustna oraz część pisemna na poziomie podstawowym) od roku szkolnego 2022/2023, Warszawa 2021, s. 17.

${ }^{9}$ Ibidem, s. 33. 
Wybrany akapit argumentacyjny: Ostatnim argumentem jest książka pod tytułem Oskar i pani Róża. Oskar, dziewięcioletni chłopak, umiera na białaczkę, zostaje mu kilka dni. Bohater książki zamknął się w sobie, nie chciał umierać. Gdy poznał panią Różę, która z wielką miłością opiekowała się chłopcem, świat stał się dla niego inny, przez dziesięć dni, które były jego ostatnimi dniami, on przeżył całe życie.

Przypadki 3 i 4 to sytuacje, w których pojawiają się przykłady, ale nie zostają użyte. W przypadku 3 należało sformułować argument brzmiący na przykład „Cierpienie pozwala nam nauczyć się ważnych rzeczy”, w 4 zaś zabrakło wprowadzającego lub kończącego akapit stwierdzenia w rodzaju „Uczucia nadają sens życiu” czy „Uczucia mogą zmienić czyjeś życie”. Jeśli takiego elementu nie ma, brak pewności, czy uczeń rozumie sens i przesłanie utworu, czy też tylko zapamiętał (mniej lub bardziej dokładnie) treść dzieła i uważa, że wystarczająco pasuje ona do tematu. Ponadto gdy uczeń ogranicza się do streszczenia dzieła kultury spoza kanonu lektur, odbiorcy nieznającemu przywołanego utworu może być trudno dostrzec związek przykładu z tezą i tematem, a przez to - ocenić trafność ,argumentu”.

Warto zatem, by uczniowie zrozumieli, że argument to nie tylko coś innego niż przykład, ale także coś od niego istotniejszego. Praca zawierająca trafne argumenty pozbawione przykładów będzie dość ogólnikowa, ale zrozumiała, przejrzysta i spójna, natomiast tekst jedynie z opisami przykładów może być dla odbiorcy nieprzekonujący, szczególnie jeśli nie zna on przywołanych dzieł. Jeśli zaś je zna, to i tak ocena sensowności wywodu wymaga większego wysiłku niż wtedy, gdy argumenty komunikuje się wprost. Idealnie oczywiście jest wtedy, gdy występują oba elementy, trafne i zharmonizowane, a każdy z nich jest rozwinięty ${ }^{10}$.

Świadomość, że argument to coś innego niż przykład, zapobiega też typowym błędom o charakterze rzeczowo-językowym:

- Ostatnim argumentem mówiącym o tym, że cierpienie ma sens, jest film Chtopiec w pasiastej piżamie.

— Moim drugim argumentem będzie sytuacja z książki Kamienie na szaniec.

- Moim pierwszym argumentem będzie bohater filmu...

- Pierwszym argumentem popierającym powyższą tezę będzie przykład z literatury na podstawie książki pod tytułem $\dot{Z} y w i$.

Mamy tu do czynienia z błędami, z jednej strony, rzeczowymi (ukazują brak wiedzy o relacji argument-przykład), z drugiej - językowymi, ponieważ naruszają łączliwość słowa argument. Zdania byłyby natomiast pod każdym względem poprawne, gdyby pojawiło się w nich określenie przykład. Pojawianiu się takich błędów sprzyja nawykowe, bezrefleksyjne stosowanie szablonów metatekstowych, zwłaszcza wyliczających (,Moim pierwszym, drugim itp. argumentem będzie..."), do czego uczniowie niejednokrotnie są zachęcani (lub nawet zobowiązywani) na początku pracy nad rozprawką ${ }^{11}$.

${ }^{10}$ M. Korolko, Sztuka retoryki. Przewodnik encyklopedyczny, Warszawa 1998, s. 90.

11 O (nad)używaniu szablonów metatekstowych w rozprawce zob. K. Kaszewski, Do czego stuży zakończenie rozprawki?, [w:] Język a Edukacja 5. Uczenie języka ojczystego w czasach pono- 
Przyczyny powyższych problemów są złożone. Po pierwsze, uczeń może mieć jeszcze niedostatecznie wykształconą umiejętność generalizacji, myślenia indukcyjnego. Jest to operacja abstrakcyjna, według Piageta, osiągalna od około 12 roku życia (stadium operacji formalnych) ${ }^{12}$. Po drugie, trudności mogą wynikać z powierzchownego lub chybionego zrozumienia tematu albo też jego nieprzyjaznego sformułowania (do tego zagadnienia jeszcze wrócę w częściach trzeciej i czwartej). Po trzecie, powodem kłopotów może być (zbyt) mała wiedza ucznia, który nie potrafi napisać niczego na temat, nie mówiąc już o zdyscyplinowanym uformowaniu wywodu. Po czwarte, w pomocach edukacyjnych nie zwraca się uwagi na różnicę między argumentem a przykładem (określenia argument i przykład stosuje się wymiennie) $)^{13}$ i mało mówi o pożądanej budowie wewnętrznej akapitu argumentacyjnego. Po piąte, problemom może sprzyjać podawczy, pamięciowy, encyklopedyczny sposób nauczania i oceniania prac — w praktyce szkolnej bywa, że wykazanie się znajomością treści utworu literackiego uznaje się za wystarczające.

Odróżnianie argumentu od przykładu pozwala też na doskonalenie ważnych umiejętności uniwersalnych. Po pierwsze, dwóch podstawowych sposobów myślenia i wnioskowania - indukcyjnego (kiedy na podstawie szeregu przykładów szczegółowych formułujemy myśl ogólną) i dedukcyjnego (kiedy do ogólnej myśli dobieramy konkretne jej praktyczne realizacje). Po drugie, doskonali warsztat między innymi w zakresie zbierania i porządkowania informacji, rozróżniania faktów i subiektywnych ocen oraz umiejętnego wykorzystania jednego i drugiego ${ }^{14}$; wzmacnia się kompetencje dotyczące jasnego formułowania myśli, sądów; ćwiczy dyscyplinę myślenia i prezentacji jego efektów. Po trzecie rozwija się zdolność interpretacji dzieł kultury i wykorzystania ich treści w praktyce, nie zaś mechanicznego odtwarzania.

\section{Odróżnianie argumentu od przykładu — co tracimy?}

Podstawowym problemem, jaki przynosi podejście zapisane $\mathrm{w}$ podstawie programowej, jest pewne oddalenie się rozprawkowej argumentacji od systemu pojęciowego i zasad klasycznej retoryki, inaczej bowiem rozumie ona pojęcie argumentu i relację argument-przykład. Argumentem w retoryce jest układ ,przesłanki + wniosek", czyli coś obszerniejszego niż w proponowanym podejściu szkolnym. Ponadto retoryce jest obce postulowane w edukacji szkolnej wyraźne przeciwstawienie argumentu i przykładu, te pojęcia są (lub mogą być) znacznie

woczesnych, red. A. Tabisz, Opole 2017; idem, Wstęp do rozprawki-oczekiwania a rzeczywistość, „Kształcenie Językowe” 15 (25), 2017.

12 R.R. Hock, 40 prac badawczych, które zmienity oblicze psychologii, przeł. E. Wojtych, Gdańsk 2003, s. 172.

13 Por. np. Z. Pomianowska, M. Zagnińska, Jak pisać rozprawkę, opowiadanie, charakterystykę..., Kraków 2021, s. 85.

${ }^{14}$ E. Bańkowska, Rozprawka - przygoda człowieka myślacego, [w:] Na językoznawczych ścieżkach. Prace ofiarowane Profesorowi Jerzemu Podrackiemu, red. A. Mikołajczuk, R. Pawelec, Warszawa 2007, s. 41. 
sobie bliższe: przykład jest uznawany za typ argumentu (określany jako rzeczowy), nie zaś jego ilustrację, uzupełnienie czy rozwinięcie ${ }^{15}$.

Nakładanie się różnych systemów terminologicznych oraz odmiennych rozumień kluczowych pojęć najpewniej powodowałoby chaos i mieszało uczniom w głowach, dlatego podczas pracy nad szkolną wypowiedzią argumentacyjną najrozsądniejsza może okazać się rezygnacja z odwołań do tradycji retorycznej. Lepiej mówić po prostu o dobrej (lub odpowiedniej czy oczekiwanej) argumentacji w rozprawce, a retorykę (po)łączyć z innymi formami wypowiedzi, na przykład przemówieniem. Zachęca do takiego podejścia także to, że w rozprawce chodzi w istocie głównie o uzasadnienie własnych sądów i ukazanie wiedzy ucznia, w niewielkim zaś stopniu — o przekonywanie do czegoś związanego z tematem ${ }^{16}$.

Powyższe rozwiązanie sprawia jednak z kolei, że w rozprawce zaczyna funkcjonować swoisty sposób argumentacji, charakterystyczny tylko dla niej, co potęguje sztuczność tej formy wypowiedzi. I bez tego rozprawka jest postrzegana jako nienaturalna i nieprzydatna życiowo (gatunek tworzony tylko w szkole); nie lubią jej i uczniowie, i niektórzy nauczyciele, co niewątpliwie utrudnia pracę i pogarsza uzyskiwane efekty.

Drugi kłopot polega na tym, że dążenie do wyraźnego różnicowania argumentów oraz przykładów oznacza w praktyce zachętę (czy nawet wyraźne zalecenie), by stosować jeden typ argumentu, w retoryce określany jako rzeczowy. Schematu „argument ogólny + przykład szczegółowy” nie można bowiem użyć w przypadku argumentów logicznych (opierają się one na wnioskowaniu z przesłanek w postaci uniwersalnej wiedzy językowej i wiedzy o świecie, a nie z indywidualnych przypadków), nie jest też zbyt naturalny przy argumentach emocjonalnych. Zmniejszamy więc $\mathrm{w}$ ten sposób potencjalną różnorodność argumentacyjną uczniowskich wypowiedzi, a jeśli chcemy jednak ją zachować, to skazujemy się na — być może karkołomne - objaśnianie, do jakiego typu argumentów uczeń powinien dobrać przykład, a do jakich nie (musi). Różnorodnych argumentów nie da się też oceniać według tych samych kryteriów.

Trzeci problem z realizacją zalecenia podstawy programowej wiąże się z tym, że nie każdy temat uznawany za rozprawkowy daje się zrealizować za pomocą postulowanego schematu argumentacyjnego. Niełatwo wskazać precyzyjnie kategorie tematów, dlatego posłużę się przykładami. Dla tematu Czy zgadzasz się ze stwierdzeniem, że w każdym jest coś, co zasługuje na podziw innych?, który pojawił się na próbnym egzaminie ósmoklasisty w 2021 r., dość trudno podać typowe argumenty „ogólne”, nie można bowiem za takie uznać wymienianie kolejnych

15 Por. argumentum ab exemplo w K. Szymanek, Sztuka argumentacji. Nowy stownik terminologiczny, Warszawa 2021.

16 Proponowane w podstawie programowej ujęcie skłania natomiast do tego, by rozprawkę silniej (niż z retoryką) wiązać z wywodem naukowym, począwszy od etymologii nazwy ('mała rozprawa'), aż do nastawienia na argumentację rzeczową na podstawie materiału empirycznego (nie jest to jednak też dowodzenie w sensie naukowym). 
cech charakteru, zachowań itp., za jakie podziwia się ludzi. Takie konkrety to bowiem przykłady — argumentami byłyby, gdyby temat brzmiał na przykład Ludzi można podziwiać za wiele rzeczy. Podobne wątpliwości można mieć w odniesieniu do tematu maturalnego w 2020 r. brzmiącego: Jak wprowadzenie elementów fantastycznych do utworu wplywa na przestanie tego utworu? Rozważ problem i uzasadnij swoje zdanie, odwolując się do podanych fragmentów ,Wesela”, do całego dramatu Stanisława Wyspiańskiego oraz do wybranego tekstu kultury. Zastosowane pytanie otwarte (jak? — o sposób, funkcję) zachęca do dość konkretnej odpowiedzi i ukazania od razu szeregu przykładów, z pominięciem poziomu argumentów „ogólnych”.

\section{Jak pracować nad rozprawkową argumentacją?}

W dalszej części artykułu przedstawiam kilka pomysłów prostych działań i ćwiczeń, które można realizować zarówno w klasach 7-8, jak też w szkole ponadpodstawowej. Mogą one pomóc uczniom formułować argumenty, dobierać do nich przykłady oraz odróżniać jedno od drugiego. Choć argumentacja jest sednem rozprawki i podobnych wypowiedzi, ćwiczenia pomagające nad nią pracować rzadko pojawiają się w różnego typu pomocach, a jeśli już są, to przybierają postać najogólniejszą z możliwych, w rodzaju „Sformułuj kilka argumentów do tezy/tematu...”.

\subsection{Dobór i sformułowanie tematu}

Jak już wskazywałem w części trzeciej, niezmiernie istotną sprawą jest dobór tematu rozprawki i jego językowe ukształtowanie. Kategoria tematów rozprawkowych jest obszerna i wewnętrznie zróżnicowana ${ }^{17}$, mieszczą się w niej zarówno te sprzyjające odróżnianiu argumentów od przykładów, jak i te, przy których będzie to dla ucznia trudniejsze lub nie będzie istotne (a może czasem niemożliwe?).

Aby wykształcić u uczniów omawianą umiejętność, warto podsuwać im tematy, przy których łatwo można formułować ogólne argumenty. Na przykład w przypadku tematu Rozum czy uczucia - czym bardziej powinniśmy kierować się $w$ życiu? uczeń stawiający tezę, iż bardziej powinniśmy się kierować uczuciami, jest w stanie sformułować argumenty w rodzaju „Uczucia pomagają budować relacje z innymi ludźmi” czy „Uczucia pozwalają działać szybko” bez odwoływania się do konkretnych przykładów i dzieł, choć oczywiście można (i warto) projektować jedno i drugie jednocześnie, tyle że ze świadomością, co jest czym i jaką pełni funkcję.

17 Zróżnicowanie tematów rozprawkowych, wskazanie ich rozmaitych „parametrów” i podziałów to kolejne ważne zagadnienie czekające na metodyczne opracowanie. 
Druga sprawa związana z formułowaniem tematu to treść części operacyjnej. Można w niej podkreślić konieczność odróżnienia argumentu od przykładu, choćby poprzez polecenie w rodzaju: Przedstaw swoje stanowisko, podaj co najmniej trzy argumenty $i$ zilustruj je przyktadami z literatury i filmów. $\mathrm{Z}$ tej podpowiedzi skorzystają oczywiście tylko ci uczniowie, którzy uważnie i ze zrozumieniem przeczytają temat, więc warto i nad tym wcześniej pracować. Sformułowania typu „odwołując się do wybranej lektury szkolnej” nie pomagają wprost uczniowi w odróżnieniu argumentu od przykładu.

Temat dobry do ćwiczeń argumentacyjno-przykładowych to zatem taki, do którego uczniowi nietrudno podać argumenty „ogólne”, niekoniecznie odwołując się od razu do konkretnych utworów.

\subsection{Sposób postawienia tezy przy temacie otwartym}

Temat otwarty jest tu rozumiany tak, że dopuszcza wiele różnych odpowiedzi, czyli pozwala postawić jedną z wielu możliwych tez. W przypadku takiego typu tematu na budowanie argumentacji ,argument-przykład” bardzo mocno wpływa sposób postawienia tezy, zwłaszcza pod względem jej ogólności-szczegółowości.

Najprościej mówiąc, teza nie może być zbyt szczegółowa, ponieważ wtedy rozwinięcie sprowadzi się do ukazania serii przykładów bezpośrednio ją potwierdzających, zabraknie zaś tego, co w rozprawce ma być argumentami. Dla przykładu: w przypadku tematu Czym dla człowieka jest dom? dość szczegółowa teza typu „Dom to dla człowieka miejsce, gdzie jesteśmy bezpieczni” sprawi, że łatwo będzie podać przykłady ją ilustrujące, natomiast trudniej — ogólne argumenty. W przypadku postawienia tezy ogólniejszej: „Dom to dla człowieka najważniejsze miejsce na świecie", dobrać argumenty będzie łatwiej, wystarczy odpowiedzieć na pytanie, dlaczego dom to dla człowieka najważniejsze miejsce (por. część 4.6). Dopiero do możliwych odpowiedzi na to pytanie (ponieważ czuje się tam bezpiecznie, ponieważ są tam najbliżsi ludzie, ponieważ ukształtował naszą tożsamość itd.) dobiera się przykłady: ilustrujące, ukonkretniające, wzbogacające, rozwijające, doprecyzowujące.

W przypadku niektórych tematów teza musiałaby być więc na tyle ogólna, żeby dało się do niej dobrać bardziej szczegółowe argumenty, a dopiero do nich — przykłady ${ }^{18}$. Praktyka szkolna pokazuje jednak, że im ogólniejsza teza, tym częściej spotyka się ze sprzeciwem nauczyciela (choć nie ma żadnego kryterium

18 Inna sytuacja występuje w przypadku takich tematów otwartych, w których wybrana odpowiedź i teza opierają się na konkretnym elemencie: Jakie polskie dzieło powinien przeczytać każdy Europejczyk? czy też Najpiękniejsze miejsce w Polsce. Tutaj nie da się modyfikować stopnia ogólności tezy. Stosunkowo łatwo dodać argumenty, trudniej może niekiedy dobrać do nich przykłady — skoro ciągle będzie mowa o jednym obiekcie, będą to raczej rozwinięcia, dodatkowe informacje, dane liczbowe itp. 
pozwalającego obiektywnie mierzyć i na tej podstawie ewentualnie krytykować stopień ogólności tezy), więc uczniowi pozostaje szukać jeszcze innych rozwiązań. Może to być teza w postaci wyliczenia (zapowiedzi) argumentów (na przykład dla przywołanego wcześniej tematu „Dom kształtuje człowieka pod względem charakteru, wyznawanych wartości oraz sposobu bycia”, choć też nie jest to wyjście całkiem bezpieczne - wszak prototypowa teza to coś bardziej syntetycznego niż lista argumentów).

\subsection{Dobieranie przykładów do argumentu}

Ćwiczenie polega na tym, że dla danej tezy formułujemy argument (stwierdzenie uniwersalne) i wspólnie dobieramy do niego co najmniej dwa przykłady z dzieł kultury. Takie działanie ukazują przypadki 5 i 6.

\section{Przypadek 5}

Temat: Czy cierpienie ma sens?

Teza: Prawda

Argument: Cierpienie może zbliżyć człowieka do Boga

Przykład 1. Dzieje św. Aleksego — Legenda o świętym Aleksym

Przykład 2. Dzieje Hioba - Biblia

itd.

\section{Przypadek 6}

Temat: Czy zgadzasz się ze stwierdzeniem, że cel uświęca środki?

Teza: Nieprawda

Argument: Koszty pewnych postępków mogą przewyższać korzyści

Przykład 1. Zabójstwo siostry ostatecznie kosztuje Balladynę życie

Przykład 2. Makbet zdobywa władzę, ale potem cierpi i ostatecznie ginie itd.

Taka operacja pokazuje lub pozwala przypomnieć, że dwa różne przykłady to nie dwa argumenty, lecz ukonkretnienie, zilustrowanie jednego argumentu. Ćwiczymy tu myślenie dedukcyjne - do ogólnej zasady dobieramy przypadki szczególne. Pozwalamy też dostrzec, że do jednego argumentu można dobrać wiele przykładów, ale nie odwrotnie — na podstawie jednego przykładu raczej nie da się zbudować kilku różnych argumentów pasujących do postawionej tezy.

\subsection{Formułowanie argumentu na podstawie serii przykładów}

Inny możliwy typ ćwiczenia polega na tym, że na podstawie co najmniej dwóch przykładów formułujemy argument (czyli: generalizację) do określonej tezy. Taką operację przedstawiają przypadki 7 i 8. 


\section{Przypadek 7}

Temat: Baśnie, mity, legendy nigdy się nie starzeją

Teza: Prawda

Przykład 1. Seria książek (i filmów) o Percym Jacksonie

Przykład 2. Gry komputerowe z serii God of War

Przyklad 3. Film Shrek itd.

Argument (= generalizacja pasująca do każdego przykładu z osobna oraz do wszystkich łącznie): Baśnie, mity, legendy wciąż są wykorzystywane w nowo powstających dziełach kultury, lub: Na podstawie baśni, mitów i legend ciągle powstają nowe dzieła kultury

\section{Przypadek 8}

Temat: Baśnie, mity, legendy nigdy się nie starzeją

Teza: Nieprawda

Przykład 1. Współcześnie wiemy, dlaczego zmieniają się pory roku, więc nikt już nie wierzy w to, że zależą one od zachowań bohaterek mitu greckiego - Demeter i Kory

Przykład 2. Językoznawcy wyjaśniają, skąd wzięła się nazwa Warszawa, więc nie wierzy się już w legendę o Warsie i Sawie

Argument (= generalizacja): Mity i legendy się zestarzały, ponieważ nie objaśniają już działania świata (dzisiaj robi to nauka)

To ćwiczenie zapewne będzie dla uczniów trudniejsze od poprzedniego, wymaga bowiem umiejętności abstrakcyjnego uogólniania. Operację można wykonywać jako ćwiczenie warsztatowe przed pisaniem rozprawki, ale także na przykład w ramach omówienia i poprawy pracy klasowej czy domowej — w sytuacji, gdy uczniowie przywołali trafne przykłady, lecz poprzestali na ich opisie, nie formułując argumentów.

\subsection{Tworzenie par argument-przykład}

Kolejne ćwiczenie może polegać na odpowiednim połączeniu podanych argumentów i przykładów - uczniowie pracują na przykład na zbiorze trzech argumentów i trzech przykładów z dzieł wszystkim znanych (kanon szkolny i/lub popularne wśród uczniów w danym okresie dzieła spoza listy lektur). Ukazuje to przypadek 9.

\section{Przypadek 9}

Temat: Baśnie, mity, legendy nigdy się nie starzeją

Teza: Nieprawda 


\begin{tabular}{|l|l|}
\hline \multicolumn{1}{|c|}{ Argument } & \multicolumn{1}{|c|}{ Przykład } \\
\hline $\begin{array}{l}\text { A. Mity i legendy się zestarzały, po- } \\
\text { nieważ nie objaśniają już działania } \\
\text { świata (dzisiaj robi to nauka) }\end{array}$ & $\begin{array}{l}\text { 1. W wielu baśniach braci Grimm pojawia się okrucien- } \\
\text { stwo, a mężczyźni są pokazywani jako ważniejsi od kobiet }\end{array}$ \\
\hline $\begin{array}{l}\text { B. Mity się zestarzały, ponieważ nie } \\
\text { wiążą się już z wiarą, religią }\end{array}$ & $\begin{array}{l}\text { 2. Starożytni Grecy czcili bogów ukazanych w mitach, } \\
\text { składali im ofiary }\end{array}$ \\
\hline $\begin{array}{l}\text { C. Niektóre baśnie się zestarzały, } \\
\text { ponieważ pokazują świat w sposób } \\
\text { dziś już nieakceptowany }\end{array}$ & $\begin{array}{l}\text { 3. Współcześnie wiemy, że zmiana pór roku wiąże się } \\
\text { z krąiem Ziemi wokół Słońca, więc nikt już nie wierzy } \\
\text { - Demeter i Kory }\end{array}$ \\
\hline
\end{tabular}

Po stworzeniu odpowiednich par można jeszcze poszukać kolejnych przykładów do użytych argumentów, a także zastanowić się nad tym, w jakiej kolejności najlepiej przedstawić powstałe akapity argumentacyjne.

\subsection{Formułowanie argumentów za pomocą pytania „dlaczego?”}

To prosta operacja, jednak bardzo przydatna z uwagi na to, że uwypukla potrzebę związku argumentów z dowodzoną tezą. Nie każdy temat dopuszcza takie ćwiczenie, jednak jest ono możliwe zwykle wtedy, gdy temat rozprawki:

a) jest gotowym twierdzeniem, dla którego trzeba stworzyć uzasadnienie, na przykład „Czytanie książek jest pożyteczne”;

b) wymaga postawienia tezy poprzez odpowiedź „tak” lub „nie” na pytanie, na przykład „Czy cierpienie me sens?”, a zwłaszcza gdy jest to pytanie pozorne, na które (prawie) wszyscy odpowiedzą jednakowo, na przykład „Czy zgadzasz się ze stwierdzeniem, że błądzić jest rzeczą ludzką?";

c) wymaga wyboru jednej z dwóch (trzech, czterech) możliwości zawartych w temacie, na przykład „Rozum czy uczucia — czym bardziej powinniśmy kierować się w życiu?";

d) jest otwarty (jest wiele możliwych odpowiedzi), a teza opiera się na wskazaniu konkretnego obiektu, na przykład ,Jakie polskie dzieło kultury powinien znać każdy Europejczyk?".

Działanie pytania „dlaczego?” pokazuje przypadek 10.

\section{Przypadek 10}

Temat: Błądzić jest rzeczą ludzką (= Ludzie popełniają błędy)

Teza: Prawda

Argumenty: Odpowiedzi na pytanie „Dlaczego ludzie popełniają błędy?”

Argument 1. Czasem działamy pod wpływem silnych emocji

Przykłady: Romeo i Julia, Jacek Soplica itd.

Argument 2. Czasem lekceważymy zagrożenie 
Przykłady: Pandora, Seth z Baśnioboru i wszyscy inni lekkomyślni, zbyt pewni siebie lub głupi bohaterowie dzieł kultury

Argument 3. Mamy ograniczoną wiedzę, nie wszystko można przewidzieć

Przykłady: Serial Dom z papieru (reż. Jesús Colmenar i in.) i inne dzieła ukazujące, jak misterny plan zawodzi wobec przypadkowych, nieprzewidzianych zdarzeń; Dekalog 1 (reż. Krzysztof Kieślowski) itd.

Zastosowanie metody „dlaczego?” wobec tematu 10 pozwala uniknąć typowego błędu polegającego na wypełnieniu rozwinięcia opisami ludzi czy postaci fikcyjnych, którzy popełnili jakiś błąd: przywołanie biblijnego syna marnotrawnego, Edypa, Romea i Julii, latarnika Skawińskiego, Balladyny, Ikara itp. W temacie chodzi bowiem o związek popełniania błędów z określonymi cechami natury człowieka, czyli przynależącymi wszystkim ludziom; nie wystarczy podać kilku przykładów postaci literackich czy filmowych, które popełniły jakiś błąd, ponieważ w ten sposób powstanie szereg przykładów, ale ani jeden argument. Dopiero sformułowanie argumentów podających przyczyny popełniania błędów jest realizacją postulowanego schematu ,argument ogólny + przykład szczegółowy”.

\subsection{Wskazywanie argumentu w akapicie argumentacyjnym}

W dostrzeganiu pożądanej budowy akapitu argumentacyjnego mogą pomóc ćwiczenia analityczne gotowych rozprawek, zarówno przykładowych (wzorcowych), jak i własnych (swoich lub innych uczniów), celem ich (u)doskonalenia - na przykład w ramach omówienia wyników pracy domowej czy klasowej. Dostrzeganie (braku) nadrzędnej, najogólniejszej myśli akapitu pomaga doskonalić umiejętność analizy tekstu, wiąże się też z refleksją nad pożądaną kompozycją akapitu argumentacyjnego.

Poprawnie zbudowany akapit argumentacyjny w rozprawce zawiera argument i co najmniej jeden przykład. Można wskazać minimum trzy warianty kompozycyjne różniące się stopniem trudności. Najbardziej przejrzysty i najłatwiejszy dla ucznia układ to taki, w którym akapit rozpoczyna się od argumentu (myśli najbardziej ogólnej), a który następnie zostaje zilustrowany konkretną sytuacją. Jest to układ dedukcyjny odzwierciedlający myślenie od ogółu do szczegółu.

Drugi podstawowy wariant to opisanie na początku sytuacji (przedstawienie przykładu), a na końcu akapitu sformułowanie argumentu jako wniosku. Jest to układ indukcyjny, realizujący tok myślenia od szczegółu do ogółu — jak się zdaje — nieco trudniejszy od poprzedniego. Taką sytuację przedstawia przypadek 11.

\section{Przypadek 11}

Temat: Czy cierpienie ma sens?

Teza: Prawda

Akapit argumentacyjny: Drugim argumentem opartym na filmie pod tytułem Trzy metry nad niebem potwierdzę, że cierpienie ma sens. Dziewczyna 
zakochana po uszy w nieodpowiednim chłopaku cierpi, mimo to nadal się z nim spotyka i myśli, że będzie dobrze. Kiedy jej cierpienie dobiega końca, zdaje sobie sprawę, że przez ten okres dużo się nauczyła. Poznała, jakie naprawdę jest życie, i ile bólu potrafi zadać. Cierpienie nauczyło ją pokory i dystansu.

Argument może też pojawić się w środku przykładu, być zrośnięty z opisem treści przywołanego dzieła kultury, jednak taka kompozycja wymaga najwyższej dyscypliny ze strony ucznia, by argument realnie wybrzmiał. Jest też trudniej dla odbiorcy niż wtedy, gdy argument zostaje wyeksponowany w strategicznej pozycji tekstowej (początek lub koniec akapitu), naturalnie skupiającej uwagę. Można więc, zwłaszcza w przypadku słabszych uczniów, ten typ kompozycji zarezerwować dla innych form wypowiedzi, na przykład zmierzających w stronę eseju.

\section{Podsumowanie}

Postulowana argumentacja w rozprawce, zwłaszcza egzaminacyjnej, jawi się jako specyficzna, inna niż w klasycznej retoryce czy formach wypowiedzi takich jak przemówienie czy zaproszenie. Schemat ,argument ogólny + przykład szczegółowy" nie jest idealny i jedynie słuszny, ponadto nie zawsze daje się zastosować, choćby z uwagi na różnorodność typów tematów, z jakimi przyjdzie się uczniom zetknąć. Zdecydowanie warto jednak z niego korzystać (częściej niż czasami), ponieważ może przynieść sporo korzyści: rozwija fundamentalną umiejętność abstrakcyjnej generalizacji, uczy zarówno myślenia indukcyjnego, jak i dedukcyjnego. Aby uczniowie poradzili sobie z tym zadaniem, potrzebują jednak pomocy - przede wszystkim odpowiednio sformułowanych tematów, ćwiczeń w ich analizowaniu, wspólnego dobierania argumentów do tezy, a przykładów do argumentów. Nieświadomość różnicy między argumentem a przykładem nie zawsze rozprawce (za)szkodzi, ale nigdy nie prowadzi do czegoś dobrego.

\section{Bibliografia}

Bańkowska E., Rozprawka - przygoda człowieka myślącego, [w:] Na językoznawczych ścieżkach. Prace ofiarowane Profesorowi Jerzemu Podrackiemu, red. A. Mikołajczuk, R. Pawelec, Warszawa 2007.

Hock R.R., 40 prac badawczych, które zmienity oblicze psychologii, przeł. E. Wojtych, Gdańsk 2003. Inny słownik języka polskiego, t. 1-2, red. M. Bańko, Warszawa 2001-2002.

INFORMATOR o egzaminie maturalnym z języka polskiego jako przedmiotu obowiązkowego (część ustna oraz czesść pisemna na poziomie podstawowym) od roku szkolnego 2022/2023, Warszawa 2021, https://cke.gov.pl/images/_EGZAMIN_MATURALNY_OD_2023/Informatory/ Informator_EM2023_jezyk_polski_PP.pdf.

Kaszewski K., Do czego stuży zakończenie rozprawki?, [w:] Język a Edukacja 5. Uczenie języka ojczystego w czasach ponowoczesnych, red. A. Tabisz, Opole 2017. 
Kaszewski K., Wstęp do rozprawki - oczekiwania a rzeczywistość, „Kształcenie Językowe” 15 (25), 2017.

Korolko M., Sztuka retoryki. Przewodnik encyklopedyczny, Warszawa 1998.

Pomianowska Z., Zagnińska M., Jak pisać rozprawkę, opowiadanie, charakterystykę..., Kraków 2021.

Rozporządzenie Ministra Edukacji Narodowej z dnia 14 lutego 2017 roku w sprawie podstawy programowej wychowania przedszkolnego oraz podstawy programowej kształcenia ogólnego dla szkoły podstawowej, w tym dla uczniów z niepełnosprawnością intelektualną w stopniu umiarkowanym lub znacznym, kształcenia ogólnego dla branżowej szkoły I stopnia, kształcenia ogólnego dla szkoły specjalnej przysposabiającej do pracy oraz kształcenia ogólnego dla szkoły policealnej, Dz.U. z 2017 r. poz. 356, http://isap.sejm.gov.pl/isap.nsf/DocDetails. xsp?id=WDU20170000356.

Szymanek K., Sztuka argumentacji. Nowy słownik terminologiczny, Warszawa 2021.

Uniwersalny słownik języka polskiego, red. S. Dubisz, Warszawa 2004. 